\title{
Crisis Situations and Information Science. Selected Issues in the Context of the COVID-19 Pandemic
}

\author{
Zuzanna Wiorogórska \\ ORCID 0000-0003-1015-2000 \\ Department of Information Studies, Faculty of Journalism, \\ Information and Book Studies \\ University of Warsaw, Poland
}

\begin{abstract}
Purpose/Thesis: This paper attempts to organize and systematize scholarly literature on the issues relating to the current global health crisis published by information science scholars and professionals, as well as on the information science-related initiatives undertaken to provide access to reliable and valid information in crisis situations.

Approach/Methods: A critical review of selected literature, as well as observation and a descriptive analysis of websites and Web platforms were conducted to establish the thematic corpus.

Results and conclusions: Even though the topic is recent, several subfields of information science have already been the subject of studies conducted in different parts of the world. It may imply that information science scholars and professionals react quickly to change and they are aware of the fact that their discipline may play an important role during crisis situations. This role may involve facilitating better management in future crises if they do happen.

Research limitations: Since the topic is new and the situation is dynamic, new research results, or online projects are being issued almost on a daily basis. Hence, it can be assumed that shortly after its publication, this paper will not present the current state of the art anymore.

Originality/Value: First scholarly publications on the issues relating to the current global health crisis appeared in early Spring 2020. According to the author's knowledge, no summary has been published that would systematize and classify the publications and other initiatives from the information science field.
\end{abstract}

Keywords

COVID-19 pandemic. Health crisis. Information science. Information studies.

Received: 13 November 2020. Reviewed: 30 November 2020. Accepted: 14 December 2020.

\section{Introduction}

The global health crisis we have been witnessing since the beginning of 2020 inspired a more general reflection on the role of information in crisis situations. As Virginia Barbour and Martin Borchert, Australian researchers, stated, "The current crisis offers an opportunity to refashion a better system" (Barbour \& Borchert, 2020), for example to build a new, more open research infrastructure and to reshape the policy of research output communication. Furthermore, the intense data production and the proliferation of channels for sharing this 
data on a daily basis have challenged current research practices; they have also moved the scholarly communication to less formal channels, proving that preprints and social media play an important role in research dissemination. It has reshaped the research culture, and made research itself more fast-paced (Kupferschmidt, 2020). It exposed the need for an innovative infrastructure that would support digital scholarly communication - a need which has already been discussed before the pandemic, during the "Digital Transformation in Scholarly Communication” workshop organized by Science Europe in November 2019 in Brussels (Science Europe, 2020).

In February 2020, International Internet Preservation Consortium (IIPC), collaborating with Archive-It, identified already existing websites and began crawling newly established websites to create a collection that would preserve Web content related to the outbreak of COVID-19 (IIPC, 2020). In April, IIPC launched a survey to map information on collecting Internet content related to the COVID-19 pandemic. The participants included libraries, archives and other institutions managing Web archive collections.

Furthermore, various associations of information management professionals have issued guidelines, recommendations; they also shared resources and tool hubs (see for ex. ALA, 2020; IFLA, 2020) to help institutions in their everyday informational work and service delivery.

This paper attempts to organize and systematize the selected scholarly literature on the issues relating to the global health crisis published by information science scholars and professionals, as well as information science-related initiatives undertaken to provide access to reliable information in critical situations.

A review of selected literature, as well as observation and a descriptive analysis of websites and Web platforms were conducted to establish the thematic corpus. Then, after introducing relevant categories, the publications were classified.

\section{Thematic coverage}

For the purposes of this paper, five information-related areas were distinguished. These were: 1 . Users; 2 . Information management strategies; 3 . Research and scholarly communication; 4. Impact of crisis situations on the development of social media content; and 5. The role of information professionals in management of crisis situations. The division was arbitrary. These areas comprised more detailed subfields and themes.

\subsection{Users}

Users need access to immediate information (Zeng et al., 2020), but they also need immediate access to information to continue their everyday research work or education regardless of the external circumstances. The sudden lockdown which prevented access to onsite information sources disrupted professional and educational plans of many, and forced the information professionals to rapidly change how they worked and to adjust the services they provided to the users' needs.

The pandemic and the resulting lockdown also revealed an urgent need to improve skills and competences relating to information literacy, which involves evaluation of sources, assessing its reliability, or critical thinking among information users. 
Several authors indicated that information overload was one of the main challenges during the pandemic (Chang et al., 2020; Zeng et al., 2020).

Ángeles Moreno et al. (2020) surveyed the influence of information forms and sources on the public information-seeking behaviors, particularly in the context of trust in diverse information sources and channels, as well as the perception of government communication management in Spain. The results of their study reflected the findings of previous research on the trust in government communication. During the first stages of an emergency the trust in those sources was moderate as was the criticism of public authorities, which became more pronounced as the crisis evolved.

Samuli Laato et al. (2020) described a phenomenon of cyberchondria in the context of the COVID-19 pandemic. Cyberchondria is extreme anxiety that might be provoked by information overload. In this case, it was caused by obsessional browsing the Web in search for medical information, which became a regular occupation of the individuals frightened by the spreading misinformation regarding the threat and casualties of COVID-19.

Rubén Alcaraz-Martínes and Mireia Ribera-Turró (2020) drew attention to a defavorized group of information users - people with low vision. Unlike people with major sight loss, this group of visually disabled users is not yet forced to rely on assistive technologies to read electronic content. Thus, certain efforts are required to ensure these users have equal access to essential information - in this case, information on the pandemic-related issues. In their study, the authors reviewed the accessibility of the statistical charts about the COVID-19 crisis published by the governments of Brazil, Russia, the UK, the USA, and the European Union. The results were satisfactory.

\subsection{Information management strategies}

The journal Data and Information Management devoted a special issue to the theme of the COVID-19 global pandemic in the context of using data and information management responses to the global health crisis. In an editorial article, Feicheng Ma (2020) highlighted three issues that in his opinion deserve serious consideration. These are: 1) accurate collection and analysis of epidemic-related data; 2 ) effective screening of erroneous/ false information; 3) user information behavior in public health emergencies.

The pandemic also challenged knowledge organization systems (KOSs), particularly health-related terminologies. To face information overload and eliminate semantic conflicts, controlled, standardized, and shared vocabularies have become critical to information exchange and communication during the COVID-19 pandemic (Zeng et al., 2020). Moreover, ontologies are in use to enhance interoperability. They link different vocabularies and data coded in diverse standards; they also allow semantic solutions to process data. COVID-19 Surveillance Ontology (NCBO, 2020b) or Coronavirus Infectious Disease Ontology (NCBO, 2020a) might serve as examples. An interesting study which experimented with merging datasets and diverse taxonomies was conducted by Yi-Yun Cheng and Bertram Ludäscher (2020).

Tomás Saorín et al. (2020) designed an algorithm that helps build controlled vocabularies relating to the COVID-19 pandemic, based on Wikidata and Wikipedia terminologies. The authors implemented the algorithm in an open-source application, which allowed them to publish the results of their work on the pandemic vocabulary collection in a repository. 
We can also observe launching of advanced aggregating platforms, which use big data analysis and computer modelling.

COVID-19 Primer (https://covid19primer.com) uses national language processing algorithms to crawl summaries of the latest research papers which it presents on a user-friendly, data dashboard updated every 24 hours.

LitCovid is an open-source literature hub tracking up-to-date international research publications on COVID-19 (Chen et al., 2020). The COVID-19 Open Research Dataset, abbreviated "CORD-19" (SST, 2020) is a free resource of over 52.000 scholarly articles about COVID-19 and the coronavirus family of viruses, which is freely available to the global research community. About 30 library guides (as cited by Yu \& Mani, 2020)academic libraries in the United States were reportedly responding to challenges by pivoting to new ways to meet the users' needs. This observational study was designed to investigate the status, services, and resources disclosed via websites of academic medical/health sciences libraries (MHSLs provides direct links to these two resources, which proves its relevancy and reliability.

A French project CoVprehension (at https://covprehension.org/) can serve as example of a user-friendly simulator of social models. It uses spatial data infrastructures to create simulations and to share data.

Data management and sharing is extremely important during crisis situations. In response to the outbreak of the current global pandemic Research Data Alliance published COVID-19 data management Guidelines and Recommendations (RDA, 2020).

\subsection{Research and scholarly communication}

In October 2020, Frontiers published a report on the survey entitled "The Academic Response to COVID-19" (Rijs \& Fenter, 2020), which was conducted between May and June 2020 among over 25.000 researchers from 152 countries. The results showed that the majority of researchers had been able to continue working; writing papers for publication has been the most common occupation during the pandemic, alongside research and online teaching. According to most of the participants, their institutions were prepared for a shift to remote working; they assessed positively the support received from their workplaces. A part of the survey concerned open science and research results sharing. Here, the answers varied significantly across different countries. Cultural differences played a part in whether researchers were more likely to publish in open access journals or share their research data. Still, in some countries, nearly half of the researchers was more likely to deposit work on a preprint server, or to share data, or to publish in an open access journal. On the other hand, a quarter of the researchers suggested that they could contribute through sharing their expertise with scholars in other disciplines. It also should be mentioned that almost half of the researchers expressed concerns about the impact of the current crisis on future funding of research.

Daniel Torres-Salinas (2020) conducted a bibliometric study focusing on scholarly articles concerned with COVID-19. The results of his work were published in March 2020. He counted nearly 9500 publication; at the time when the daily global growth rate was 500 publications (in PubMed database even 1000), with the production doubling every 15 days. More than a half year later, those numbers are certainly out of date and probably have grown 
significantly. Torres-Salinas concluded that three out of four publications analyzed were available in open access. In the light of the abovementioned Frontiers' report, this allows for more optimism when it comes to sharing of the research results.

\subsection{Impact of crisis situations on the development of social media content}

Another interesting field of investigation for information science is the spread of information in social media in a crisis situation. As a microblog, Twitter is a popular means for rapid sharing information with large numbers of people. The platform is more and more frequently used as an official information channel by public institutions, such as governments or health public agencies. This is likely why tweets were the most often analyzed means of communication in information science scholarship (Chong, 2020; Dinh \& Parulian, 2020; Fan et al., 2020; Karami \& Anderson, 2020; Thelwall \& Thelwall, 2020; Zheng et al., 2020).

YouTube was studied by Enrique Orduña-Malena et al. (2020). They conducted an informetrics study and analyzed over 39.000 videos between January and April 2020 to characterize the impact of those videos and to categorize the broadcast channels.

\subsection{The role of information professionals in management of crisis situations}

Jiangping Chen conducted a small study among her doctoral students in information studies at the University of North Texas (Chen, 2020). She wanted to investigate the students' (future information science scholars) perspectives on what information scientists can do to help individuals and societies to survive global health crises such as the COVID-19 pandemic. The participants identified six key responsibilities: (1) fighting against misinformation and disinformation; (2) collaboration (involved in point 1; this may also refer to interdisciplinary and interinstitutional collaboration which could help vulnerable populations to access information and resources; (3) research on information behavior (which also helps in preventing information overload and the abovementioned cyberchondria); (4) digital archiving (since archives of material created in these extraordinary circumstances will allow for later comparative analyses in other fields); (5) information access for vulnerable populations (which are often disadvantaged even at the best of times) to equip them with digital technologies and information skills; (6) information and data literacy.

The latter is not only the key responsibility of information scientists, but, more importantly, the key 21 st century skill for all individuals which they should constantly improve through formal and non-formal life-long learning; the skill indispensable for the critical evaluation of sources and information (information literacy) and processing, sorting, and filtering vast quantities of information, which require knowing how to search, how to filter and process, to produce and synthesize that information (i.e., data literacy as defined by Koltay, 2016).

Dora Sales et al. (2020) examined how social sciences faculty assessed their own and their students' levels of information and digital competences (IDC). The results showed that the lockdown which forced them to move their teaching online (a process which the authors called "virtualization of teaching") revealed certain gaps and deficits at both parties of didactic process. Considering that IDC is a key component of inclusive and sustainable society, 
university authorities should consider implementing a systematic institutional solution to facilitate the development of IDC. Academic libraries may be partners in this endeavor.

Libraries and librarians are also important players on the field of information. Although they have been traditionally perceived as primarily responsible for book curation and preservation, in reality they have long served as mediators between analog or digital documents, and the information users. And during this difficult period, which some authors identified as an "infodemic" (cf. Aleixandre-Benavent et al., 2020; García-Marín, 2020; Yu \& Mani, 2020), librarians were continuously and actively responding to the patrons' needs.

In the USA, at the early stage of the pandemic, a nation-wide online survey on the US Academic Library Response to COVID-19 was launched (Janicke Hinchliffe \& Wolff-Eisenberg, 2020). The survey explored strategies employed by the libraries during lockdown and the challenges they were facing while shifting online the delivery both of library services (what impacted them directly) and of teaching (what impacted their patrons).

Among several types of libraries, medical and health science libraries are assigned a singular task. Not only do they serve their users in everyday queries, they also need to quickly adapt to crisis situations in order to provide services that will equip the researchers with the latest and relevant information necessary to find the methods to overcome the disease. In March and April 2020, Fei Yu and Nandita Mani (2020) conducted an observational study in 157 libraries of that type in the USA. They concluded that the expertise of medical and health science libraries helped to combat the information crises brought on by the pandemic; librarians partnered with healthcare professionals, public health leaders, and policymakers.

The authors of this study also emphasized the importance of health literacy education and data management. To ensure the former, libraries provided guidance on the evaluation of information and fact-checking. Some of the surveyed libraries redirected their users towards another noteworthy project that has shaped health literacy and fights against misinformation, i.e., "The COVID-19 Health Literacy Project" at https://covid19healthliteracyproject.com. It offers coronavirus fact sheets in more than 30 languages. The project was a grass-roots initiative of a Harvard Medical School student, but it quickly turned into a coalition of US medical students representing several language groups, further fostering its multilingualism.

The call for papers published by a Canadian journal Documentation et bibliothèques, for its thematic issue entitled Be a part of the equation (Fr. Faire partie de l'équation), to be published in 2021, focuses on improving the position of informational professionals and the services they may offer in times of the pandemic (ASTED, 2020). It seems that this topic is inexhaustible and is constantly inspiring new ideas.

\section{Conclusion}

Even though the theme and the exceptional circumstances in which we are living have a very brief history, several subfields of information science and their relation to the global health crisis have already been studied in different parts of the world. It might imply that information science scholars and professionals react quickly and that they are aware that their discipline may play an important role during crisis situations. This role may facilitating 
better management in future crises - if they do happen. Due to the topic's novelty and dynamics, new results of studies, or online projects are being issued almost on a daily basis. Hence, it can be assumed that shortly after its publication, this paper will not present the current state of the art anymore. Therefore, a further, more thorough study could be conducted in few months and / or after the pandemic ends, to expand and update the initial review of literature presented in this paper.

\section{References}

ALA (2020). Pandemic Preparedness. Resources for Libraries [online]. American Libraries Association [13.11.2020], http://www.ala.org/tools/atoz/pandemic-preparedness

Alcaraz-Martínez, R., Ribera-Turró, M. (2020). An Evaluation of Accessibility of Covid-19 Statistical Charts of Governments and Health Organisations for People with Low Vision. El Profesional de La Información, 25(5), https://doi.org/10.3145/epi.2020.sep.14

Aleixandre-Benavent, R., Castelló-Cogollos, L., Valderrama-Zurián, J.-C. (2020). Información y comunicación durante los primeros meses de Covid-19. Cronología, infodemia y desinformación, noticias falsas, investigaciones en curso y papel de los especialistas en información. El Profesional de La Información, 29(4), https://doi.org/10.3145/epi.2020.jul.08

ASTED (2020). Appel de texte Documentation et bibliothèques - Volume 67, no 1: Faire partie de l'équation [online]. L'Association pour l'avancement des sciences et des techniques de la documentation [13.11.2020], https://tinyurl.com/y3vhrrtz

Barbour, V., Borchert, M. (2020). Open Science: After the COVID-19 Pandemic There Can Be No Return to Closed Working [online]. Australian Academy of Science [13.11.2020], https://www. science.org.au/curious/policy-features/open-science-after-covid-19-pandemic-there-can-beno-return-closed-working

Chang, S., McKay, D., Caidi, N., Mendoza, A., Gomes, C., Dedeoglu, C. E. (2020). From Way Across the Sea: Information Overload and International Students During the COVID-19 Pandemic. Proceedings of the Association for Information Science and Technology, 57(1), https://doi.org/10.1002/pra2.289

Chen, J. (2020). Beyond Information Organization and Evaluation: How Can Information Scientists Contribute to Independent Thinking? Data and Information Management, 4(3), 171-176, https:// doi.org/10.2478/dim-2020-0017

Chen, Q., Allot, A., Lu, Z. (2020). Keep up With the Latest Coronavirus Research. Nature, 579(7798), 193.

Cheng, Y., Ludäscher, B. (2020). Through the Magnifying Glass: Exploring Aggregations of COVID-19 Datasets by County, State, and Taxonomies of U.S. Regions. Proceedings of the Association for Information Science and Technology, 57(1), https://doi.org/10.1002/pra2.355

Chong, M. (2020). Network Typology, Information Sources, and Messages of the Infodemic Twitter Network Under COVID-19. Proceedings of the Association for Information Science and Technology, 57(1), https://doi.org/10.1002/pra2.363

Dinh, L., Parulian, N. (2020). COVID-19 Pandemic and Information Diffusion Analysis on Twitter. Proceedings of the Association for Information Science and Technology, 57(1), https://doi. org/10.1002/pra2.252

Fan, L., Yu, H., Yin, Z. (2020). Stigmatization in Social Media: Documenting and Analyzing Hate Speech for COVID-19 on Twitter. Proceedings of the Association for Information Science and Technology, 57(1), https://doi.org/10.1002/pra2.313

García-Marín, D. (2020). Infodemia global. Desórdenes informativos, narrativas fake y fact-checking en la crisis de la Covid-19. El Profesional de La Información, 29(4), https://doi.org/10.3145/ epi.2020.jul.11 
IFLA (2020). COVID-19 and the Global Library Field [online]. International Federation of Libraries and Associations [13.11.2020], https://www.ifla.org/covid-19-and-libraries

IIPC (2020). Novel Coronavirus (COVID-19) [online]. International Internet Preservation Consortium [13.11.2020], https://archive-it.org/collections/13529

Janicke Hinchliffe, L., Wolff-Eisenberg, C. (2020). US Academic Library Response to COVID19 Survey [online]. Google Docs. Public Document of Links [13.11.2020], https://docs.google.com/ document/d/e/2PACX-1vTUm3ZmNwiYXG6ghLmYYSJ7FbB7vqYhQQaokqne18J68GSLufY6Z HguNi16zJMXl10a0HaiBgROR-R7/pub

Karami, A., Anderson, M. (2020). Social Media and COVID-19: Characterizing Anti-Quarantine Comments on Twitter. Proceedings of the Association for Information Science and Technology, 57(1), https://doi.org/10.1002/pra2.349

Koltay, T. (2016). Data Governance, Data Literacy and the Management of Data Quality. IFLA Journal, 42(4), 303-312, https://doi.org/https://doi.org/10.1177/0340035216672238

Kupferschmidt, K. (2020). 'A Completely New Culture of Doing Research.' Coronavirus Outbreak Changes How Scientists Communicate. Science, (26 Feb.), https://doi.org/10.1126/science.abb4761

Laato, S., Islam, A. K. M. N., Islam, M. N., Whelan, E. (2020). What drives unverified information sharing and cyberchondria during the COVID-19 pandemic? European Journal of Information Systems, 29(3), 288-305, https://doi.org/10.1080/0960085X.2020.1770632

Ma, F. (2020). How Can Information and Data Management Be Used to Address Global Health Crisis. Data and Information Management, 4(3), 127-129, https://doi.org/10.2478/dim-2020-0018

Moreno, A., Fuentes-Lara, C., Navarro, C. (2020). Covid-19 Communication Management in Spain: Exploring the Effect of Information-Seeking Behavior and Message Reception in Public's Evaluation. El Profesional de La Información, 29(4), https://doi.org/10.3145/epi.2020.jul.02

NCBO (2020a). Coronavirus Infectious Disease Ontology [online]. National Center for Biomedical Ontology [13.11.2020], from https://bioportal.bioontology.org/ontologies/CIDO

NCBO (2020b). COVID-19 Surveillance Ontology [online]. National Center for Biomedical Ontology [13.11.2020], https://bioportal.bioontology.org/ontologies/COVID19/

Orduña-Malea, E., Font-Julián, C. I., Ontalba-Ruipérez, J.-A. (2020). Covid-19: análisis métrico de vídeos y canales de comunicación en YouTube. El Profesional de La Información, 29(3), https:// doi.org/10.3145/epi.2020.jul.01

RDA (2020). RDA COVID-19 Guidelines and Recommendations [online]. Reseacrh Data Alliance [13.11.2020], https://www.rd-alliance.org/group/rda-covid19-rda-covid19-omics-rda-covid19epidemiology-rda-covid19-clinical-rda-covid19-0

Rijs, C., Fenter, F. (2020). The Academic Response to COVID-19. Frontiers in Public Health, 8, https:// doi.org/10.3389/fpubh.2020.621563

Sales, D., Cuevas-Cerveró, A., Gómez-Hernández, J.-A. (2020). Perspectives on the Information and Digital Competence of Social Sciences Students and Faculty Before and During Lockdown Due to COVID-19. El Profesional de La Información, 29(4), https://doi.org/10.3145/epi.2020.jul.23

Saorín, T., Pastor-Sánchez, J.-A., Baños-Moreno, M.-J. (2020). Uso de Wikidata y Wikipedia para la generación asistida de un vocabulario estructurado multilingüe sobre la pandemia de Covid-19. El Profesional de La Información, 29(5), https://doi.org/10.3145/epi.2020.sep.09

Science Europe (2020). Digital Transformation in Scholarly Communication Event Report [online]. Science Europe [13.11.2020], http://www.scienceeurope.org/media/yyjngo3x/se-workshop-report-digital-transformation.pdf

SST (2020). CORD-19. COVID-19 Open Research Dataset [online]. Semantic Scholar Team [13.11.2020], https://www.semanticscholar.org/cord19

Thelwall, M., Thelwall, S. (2020). COVID-19 Tweeting in English: Gender Differences. El Profesional de La Información, 29(3), https://doi.org/10.3145/epi.2020.may.01 
Torres-Salinas, D. (2020). Ritmo de crecimiento diario de la producción científica sobre Covid-19. Análisis en bases de datos y repositorios en acceso abierto. El Profesional de La Información, 29(2), https://doi.org/10.3145/epi.2020.mar.15

Yu, F., Mani, N. (2020). How American Academic Medical/Health Sciences Libraries Responded to the COVID-19 Health Crisis: An Observational Study. Data and Information Management, 4(3), 200-208, https://doi.org/10.2478/dim-2020-0013

Zeng, M. L., Hong, Y., Clunis, J., He, S., Coladangelo, L. P. (2020). Implications of Knowledge Organization Systems for Health Information Exchange and Communication during the COVID-19 Pandemic. Data and Information Management, 4(3), 148-170, https://doi.org/10.2478/dim-2020-0009

Zheng, H., Goh, D. H. -L., Lee, C. S., Lee, E. W. J., Theng, Y. L. (2020). Uncovering Temporal Differences in COVID-19 Tweets. Proceedings of the Association for Information Science and Technology, 57(1), https://doi.org/10.1002/pra2.233

\title{
Sytuacje kryzysowe a nauka o informacji. Wybrane zagadnienia w kontekście pandemii COVID-19
}

\begin{abstract}
Abstrakt
Cel/Teza: Celem artykułu jest usystematyzowanie piśmiennictwa z zakresu nauki o informacji, powiązanego ze światowym kryzysem zdrowia, a opublikowanego przez badaczy nauki o informacji oraz praktyków zarządzania informacji, a także innych inicjatyw powiązanych z nauką o informacji, powziętych w celu ułatwiania dostępu do rzetelnej i jakościowej informacji w sytuacjach kryzysowych. Koncepcja/Metody badań: Wykorzystano krytyczną analizę wybranego piśmiennictwa oraz stron i platform internetowych.

Wyniki i wnioski: Mimo, że tematyka jest nowa, wiele pól zainteresowań nauki o informacji zdążyło już zostać przedmiotami badań prowadzonych w różnych częściach świata. Można zatem wnioskować, że badacze nauki o informacji oraz praktycy zarządzania informacji szybko reagują na zmiany, oraz że są świadomi ważności roli, jaką pole ich działań naukowych i zawodowych może odgrywać podczas sytuacji kryzysowych. Roli, która może także ułatwić lepsze zarządzanie podczas kolejnych kryzysów, jeśli do takich dojdzie w przyszłości.

Ograniczenia badań: Jako że tematyka jest nowa i rozwija się dynamicznie, wiele rezultatów nowych badań oraz nowe projekty wirtualne ukazują się niemal codziennie. Dlatego można założyć, że krótko po publikacji niniejszy artykuł nie będzie przedstawiał aktualnego stanu badań.

Oryginalność/Wartość poznawcza: Pierwsze publikacje naukowe dotyczące obecnego światowego kryzysu zdrowia ukazały się wiosną 2020 r. Zgodnie z wiedzą autorki jak dotąd nie ukazało się żadne podsumowanie systematyzujące i klasyfikujące publikacje oraz inne inicjatywy dotyczące nauki o informacji w tym kontekście.
\end{abstract}

\section{Słowa kluczowe}

Nauka o informacji. Pandemia COVID-19. Światowy kryzys zdrowia.

ZUZANNA WIOROGÓRSKA, PhD, is Assistant Professor at the Faculty of Journalism, Information and Book Studies, University of Warsaw, Academic Librarian at the University of Warsaw Library, and Associate Member of Laboratoire GERiiCO (University of Lille, France). Her main areas of interest include research data management, information literacy in multicultural context, users of information, and 21st century skills. Her most important recent publications are: Research Data: Management and Opening. Polish and European Perspectives (Zagadnienia Informacji Naukowej, 2019, https://doi.org/10.36702/zin.14); Data 
Literacy and Research Data Management in Two Top Universities in Poland. Raising Awareness (2018, co-authors: J. Leśniewski, E. Rozkosz, E.; published in: S. Kurbanoğlu, J. Boustany, S. Špiranec, E. Grassian, D. Mizrachi (eds), Information Literacy in the Workplace: 5th European Conference, ECIL 2017, Cham: Springer. https://doi.org/10.1007/978-3-319-74334-9_22); The Importance of Information Literacy for Asian Students at European Universities: Outlines (2018, Paideia, https://doi.org/10.33034/PAIDEIA.2018.6.1.103); Nauka o informacji w okresie zmian. Innowacyjne usługi informacyjne (co-editors: B. Sosińska-Kalata, P. Tafitowski, Warszawa, 2017).

Contact to the Author:

z.d.wiorogorska@uw.edu.pl

Department of Information Studies

Faculty of Journalism, Information and Book Studies

University of Warsaw

Nowy Świat 69

00-046 Warsaw, Poland 